\title{
Facile and Green Route to Silver Nanoparticles Using Aqueous Plant Extract, and their Photocatalytic and Antibacterial Studies
}

\author{
Elias Emeka ELEMIKE ${ }^{1}$, Damian Chinedu ONWUDIWE ${ }^{2,3}$ *, Tanzim SAIYED ${ }^{2,3}$, \\ Anthony Chinonso EKENNIA ${ }^{4}$, Mayowa Akeem AZEEZ ${ }^{5}$
}

\author{
${ }^{1}$ Department of Chemistry, Federal University of Petroleum Resources, P.M.B. 1221 Effurun, Nigeria \\ ${ }^{2}$ Material Science Innovation and Modelling (MaSIM) Research Focus Area, Faculty of Natural and Agricultural Sciences, \\ North-West University, Mafikeng Campus, Private Bag X2046, Mmabatho 2735, South Africa \\ ${ }^{3}$ Department of Chemistry, School of Physical and chemical Sciences, Faculty of Natural and Agricultural Sciences, North- \\ West University, Mafikeng Campus, Private Bag X2046, Mmabatho 2735, South Africa \\ ${ }^{4}$ Department of Chemistry, Alex Ekwueme Federal University Ndufu-Alike (AE-FUNAI), Ikwo, P.M.B 1010 Abakiliki, \\ Ebonyi State, Nigeria \\ ${ }^{5}$ Department of Industrial Chemistry, Ekiti State University, P.M.B 5363 Ado Ekiti, Ekiti State, Nigeria
}

cross ref http://dx.doi.org/10.5755/j01.ms.26.4.23017

Received 24 March 2019; accepted 23 July 2019

\begin{abstract}
Silver nanoparticles were prepared through an environmental friendly and cost-effective plant-mediated technique, using crude extracts of Welsh onion plant. The synthesized nanoparticles were characterized using UV-vis spectrophotometer, powdered X-ray diffractometer (p-XRD), Fourier transform infra-red (FTIR) spectrophotometer, and transmission electron microscope (TEM). Silver nanoparticles of different sizes and morphologies were obtained by varying some synthesis parameters such as concentrations of $\mathrm{AgNO}_{3}(1,2$ and $5 \mathrm{mM})$ and ratio of the volume of the plant extract to $\mathrm{AgNO}_{3}(1: 5$ and $1: 10)$ at constant reaction temperature of $80^{\circ} \mathrm{C}$. The difference in the reaction conditions showed significant effects on silver nanoparticles obtained. The surface plasmon resonance (SPR) varied with change in concentration of $\mathrm{AgNO}_{3}$ and the ratio of the $\mathrm{AgNO}_{3}$ to the plant extracts. The lowest SPR appeared around $412 \mathrm{~nm}(2 \mathrm{mM} ; 1: 10)$, while the largest was achieved around $427 \mathrm{~nm}(5 \mathrm{mM} ; 1: 10)$. FTIR results revealed the presence of different characteristic functional groups responsible for the bioreduction of silver ions in Welsh onion extract. Transmission electron microscopy (TEM) showed that the lowest average particle size of the silver nanoparticles was $3.74 \mathrm{~nm}(2 \mathrm{mM} ; 1: 10)$, while the highest was $15.72 \mathrm{~nm}$ $(1 \mathrm{mM} ; 1: 5)$. Monodispersed spherical shaped nanoparticles were obtained from the $2 \mathrm{mM}$ concentration of the $\mathrm{AgNO}_{3}$, while particles with some degree of agglomeration were obtained from 1 and $5 \mathrm{mM}$ concentration. The p-XRD studies revealed face centred cubic structures. The nanoparticles obtained from 1 and $5 \mathrm{mM}$ (1:5) gave moderate photo-catalytic potentials in the degradation of methyl red dye. However, the photocatalytic property increased with increase in the concentration of the precursor salt $\left(\mathrm{AgNO}_{3}\right)$ from 1 to $5 \mathrm{mM}$. Gram positive Staphylococcus aureus and Bacillus cereus and Gram negative Klebsiela pneumonia and Escherichia coli bacteria strains were susceptible to the silver nanoparticles $(2 \mathrm{mM})$. The nanoparticles were most active against $E$. coli with a minimum inhibitory concentration (MIC) below $0.05 \mathrm{mg} / \mathrm{mL}$. The silver nanoparticles could become potential compounds in the future antibiotic research.

Keywords: green synthesis, nanoparticles, antibacterial, photocatalysis.
\end{abstract}

\section{INTRODUCTION}

The small size to large surface ratio and morphology of nanoparticles provides them with unique physical and chemical properties, which are different from the precursor or bulk material [1]. Silver nanoparticles (Ag-NPs) are characterised by high electrical and thermal conductivity, surface-enhanced Raman scattering, chemical stability, catalytic activity and non-linear optical behaviour [2]. These properties make them of potential value in inks, coatings, microelectronics, and medical imaging [3]. Ag-NPs have been extensively reported to exhibit broad spectrum bactericidal and fungicidal activity [4]. However, particle size, morphology, surface charge, functionalisation, and core structure of the nanoparticles determine their cellular uptake, cellular activation, as well as intercellular distribution of silver nanoparticles through the cell membranes of microbes [5]. Silver nanoparticles of smaller sizes tend to release silver ions faster compared to larger particles and, thus, are more toxic due to a higher concentration of silver ions in the microbial cells [6]. Various shapes (cubes, platelets, rods, rings and bipyramids) of Ag-NPs have been reported to exhibit antimicrobial properties [7, 8]. However, the reports are not consistent as to restrict their toxicity in biological media to a particular shape of the nanoparticles, rather they are linked to the density of the atoms on surface facets of the nanoparticles [9].

Different physical and chemical methods are employed in the synthesis of nanoparticles. Some of these methods are not economically feasible and environmental friendly. Green methods of nanoparticle synthesis have been embraced due to the fact that they provide biocompatible, low toxicity and eco-friendly method of synthesis [10]. The

\footnotetext{
${ }^{*}$ Corresponding author. Tel.: +27183892545.

E-mail address: damian.onwudiwe@nwu.ac.za (D.C Onwudiwe)
} 
use of various aqueous plant extracts and plant slurry in the synthesis of silver nanoparticles have been reported [11]. The effectiveness of this method is attributed to the presence of some secondary metabolites such as terpenoids, flavonoids, phenolics, carbonyl compounds, and alkaloids in the plant extracts. These components possess reducing and stabilizing properties which is utilised in biosynthesis of nano-sized materials [12]. The surface characteristics, size distribution, and morphology of silver nanoparticles can be controlled by controlling the experimental conditions. More specifically, the quantity of the plant metabolites with reducing ability in the reaction mixture and its molar ratio relative to silver precursor are major determinant of the physical properties of the resulting nano product [13].

The substrate of interest in this research is Welsh onion (Spring onion), which is also called Allium fistulosum. It belongs to the family Amaryllidaceae. The herb is indigenous to China, Eurasia and North America [14]. Phytochemical screening of the plant extract revealed major isolates as flavonoids, fatty acids (with the sulphur compounds making up about $82-87 \%$ of the total volatiles in the distilled oils), carbonyl compounds (aldehydes and ketones) constitute only $3.4 \%$ and $7.4 \%$ of the total volatiles in the compound and methyl ethyl trisulphide (which is the most abundant among all the volatile compounds isolated from Welsh onions) [15]. Welsh onion has been used as antifungal, antibacterial, antiseptic, antihelminthic and antioxidant agents in Chinese medicines due to its sulphur containing compounds [16]. Other health benefits of the plant include the increase in activities of internal organs, enhancement of metabolism, improved eyesight, aiding of digestion, and promotion of wound healing $[17,18]$.

This study aims at the synthesis of Ag-NPs using aqueous Welsh onion extract. The effects of the variation in the concentrations of precursor on the size and morphology of $\mathrm{Ag}-\mathrm{Nps}$ is reported. The photocatalytic degradation of methyl red and the antimicrobial effect of the nanoparticles on Gram positive Staphylococcus aureus and Bacillus cereus and Gram negative Klebsiela pneumonia and Escherichia coli bacteria strains was studied.

\section{MATERIALS AND METHODS}

\subsection{Materials}

Welsh Onion leaves was collected from Surat, Gujarat, India and identified by a Botanist. Silver nitrate $\left(\mathrm{AgNO}_{3}\right.$, 99\%, Merck, Germany), methyl red, 3-(4, 5dimethylthiazol-2-yl)2,5-diphenyltetrazolium bromide (MTT), agar (Merck, USA) were used without further purification to conduct all experiments.

\subsection{Preparation of Welsh onion}

The leaves were properly washed with deionized water, dried and crushed into fine particles. The particles were soaked with $150 \mathrm{~mL}$ of deionized water and subsequently filtered. The aqueous extract was obtained in a clean $150 \mathrm{~mL}$ beaker and was used for the synthesis of silver nanoparticles.

\subsection{Silver nanoparticles (Ag-NPs) synthesis using welsh onion extract}

The synthesis of the silver nanoparticles was carried out according to reported methods $[19,20]$. The reaction mixtures consist of different concentrations of $\operatorname{AgNO}_{3}(1,2$, and $5 \mathrm{mM}$ ) with different ratio (1:5 and 1:10) of plant extract to $\mathrm{AgNO}_{3}$ solutions. The reaction mixtures were heated at $80{ }^{\circ} \mathrm{C}$ and stirred. Samples were collected at intervals from the reaction system to monitor the rate of formation of the nanoparticles. Spectrophotometric absorption measurements were recorded for each of the trials during the reaction time. The appearance of yellow to slight brownishyellow colouration in the reaction mixture is indicative of the formation of Ag-NPs. In addition, the appearance of a surface plasmon resonance (SPR) peak in the range $400-450 \mathrm{~nm}$ in the absorption spectrum is significant for Ag-NPs [20]. At the end of the reaction, the nanoparticles were collected, centrifuged at $10000 \mathrm{rpm}$ for $15 \mathrm{~min}$ and dried in an oven at $50{ }^{\circ} \mathrm{C}$ for further characterisation.

\subsection{Instrumental characterization of the silver nanoparticles}

The formation of the nanoparticles was monitored using Varian Cary 300 Bio UV-visible spectrophotometer scanned in the range of $200-800 \mathrm{~nm}$. The components of the extract responsible for reduction of the $\mathrm{Ag}^{+}$ion to $\mathrm{Ag}$ were analysed using Bruker alpha-P FTIR spectrophotometer (wavenumber range of $\left.400-4000 \mathrm{~cm}^{-1}\right)$.

The different sizes of the nanoparticles were determined using JEOL2100 transmission electron microscope (TEM) and Image $\mathbf{J}$ software. XPERT-PRO powdered X-ray diffractometer ( $\mathrm{p}$-XRD) operating on monochromatic $\mathrm{Cu}$ $\mathrm{K} \alpha$ radiation $\left(\mathrm{K}=1.5406 \mathrm{~A}^{\circ}\right)$ at $40 \mathrm{kV}$ and $30 \mathrm{~mA}$ at a $2 \theta$ angle pattern was used to obtain the crystalline size nanoparticles in the region of $20-80$ [21].

\subsection{Photocatalytic degradation of methyl red using the silver nanoparticles}

The photocatalytic activity of the silver nanoparticles was evaluated using methylene blue (MB). UV light irradiation from 15-watt mercury lamp was employed as light source. The method employed was according to already established procedure [20]. Prior to illumination, $10 \mathrm{mg}$ of the nanoparticles was added to $100 \mathrm{~mL}$ of methyl red $(20 \mathrm{mg} / \mathrm{L})$ solution. The solution was properly stirred and agitated initially in the dark to ensure equilibrium and after $1 \mathrm{~h}$ was subjected to UV illumination for $2 \mathrm{~h}$. Aliquots of solutions were taken after 20,40, 60, 90 and $120 \mathrm{~min}$ and analysed with UV-vis spectrophotometer in order to study the degradation of the methyl red by the nanocatalyst. The individual concentrations of the dyes at those times were obtained and percentage degradation obtained using the equation:

Percentage $(\%)$ Dye degradation $=\frac{C_{o}-C_{t}}{C_{o}} \times 100$,

where $C_{\mathrm{o}}$ is the concentration of the dye at the start of the reaction and $C_{\mathrm{t}}$ is the concentration at time $t$. 


\subsection{Antibacterial analysis of the synthesized silver nanoparticles}

The antibacterial properties of the nanoparticles were evaluated according to reported methods [21, 22]. The agar well diffusion method was used for the antibacterial analysis of the nanoparticles with slight modification in the standard method. The test organisms utilised in this study were clinical isolates of Gram-negative, Escherichia coli and Klebsiella pneumonia; and Gram-positive Staphylococcus aureus and Bacillus cereus bacteria strains. Petri dishes were prepared and sterilized and pure culture $\left(10^{6} \mathrm{CFU} / \mathrm{mL}\right)$ streaked on them by the aid of a cotton swab. The set up was dried for $15 \mathrm{~min}$ and $6 \mathrm{~mm}$ wells were dug with a cork borer at the surface of the plates. The wells were loaded with $0.5 \mathrm{mg} / \mathrm{mL}$ concentrations of the nanoparticles and one of the well contained ciprofloxacin as the positive control drug. The plates were then incubated at $37^{\circ} \mathrm{C}$ for $24 \mathrm{~h}$. Appearance of purple colouration after addition of approx. $10 \mu \mathrm{L}$ of $1.25 \mathrm{mg} / \mathrm{mL}$ of 3-(4, 5-dimethylthiazol-2-yl)2,5diphenyltetrazolium bromide (MTT) revealed the growth of microbes. Zones of inhibition measured in $\mathrm{mm}$ were seen as sensitivity of the test microorganisms towards the nanoparticles. Duplicate experiments were made to reproduce results as mean $\pm \mathrm{S}$.D and values $<6 \mathrm{~mm}$ were considered inactive against microorganisms.

The MIC was determined according to reported methods [22] using a concentration of (0.05, 0.1, $0.25 \mathrm{mg} / \mathrm{mL}$ ) of the silver nanoparticle.

\section{RESULTS AND DISCUSSION}

The reaction of the silver nitrate salt $\left(\mathrm{AgNO}_{3}\right)$ with the Welsh onion plant extract (WPE) is expected to proceed following the steps shown in Eq. 2 and Eq. 3, with the components of the aqueous plant extracts acting as reducing agents:

$\mathrm{AgNO}_{3} \rightarrow \mathrm{Ag}^{+}+\mathrm{NO}^{-}$

WPE

$\mathrm{e}^{-}+\mathrm{Ag}^{+} \rightarrow \mathrm{Ag}^{0}$

\subsection{UV-Vis spectroscopy}

The formation of AgNPs was confirmed by the observation of the surface plasmon resonance (SPR) bands

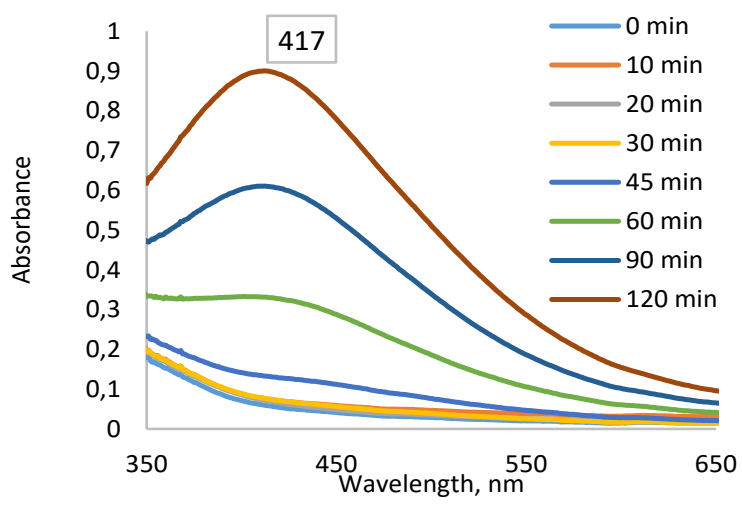

which could be influenced by the size, morphology, composition, aggregation, and dielectric environment of the prepared nanoparticles $[23,24]$. In this study, the concentrations of $\mathrm{AgNO}_{3}$ were varied and the temperature of reaction was maintained in order to obtain varying sizes of AgNPs. The surface plasmon resonance (SPR) band was first observed after $60 \mathrm{~min}$ at $417 \mathrm{~nm}$ for the $1 \mathrm{mM} \mathrm{AgNO}_{3}$ (1:5) solution, and after $90 \mathrm{~min}$ at $418 \mathrm{~nm}$ for $1 \mathrm{mM} \mathrm{AgNO}_{3}$ (1:10) solution as shown in Fig. $1 \mathrm{a}$ and $\mathrm{b}$ respectively. The surface plasmon resonance bands appeared after 60 and $45 \mathrm{~min}$ for the $2 \mathrm{mM}$ of silver nitrate solutions with 1:5 and 1:10 ratios around $418 \mathrm{~nm}$ and $412 \mathrm{~nm}$ respectively (Fig. 2). Using $5 \mathrm{mM}$ of $\mathrm{AgNO}_{3}$ solutions with 1:5 and 1:10 ratios, the SPR bands occurred after $45 \mathrm{~min}$ at 423 and $427 \mathrm{~nm}$ respectively as shown in Fig. 3.

The absorption peaks were red shifted with increasing concentration in solutions with 1:5 ratio, indicating increase in particle size with concentration. However, in the 1:10 ratio, there was a blue shift of the absorption maximum with increase in concentration from 1 to $2 \mathrm{mM}$ due to a decrease in particle size and a red shift in absorption maximum for $5 \mathrm{mM}$ which is ascribed to increase in particle size [24]. Among the three concentrations, it was observed that the solution of $5 \mathrm{mM}$ with 1:10 ratio has the largest SPR band, which suggests the presence of larger sized nanoparticles. While the SPR band obtained from $2 \mathrm{mM} \mathrm{AgNO}_{3}$ solution at 1:10 ratio has the lowest wavelength and, thus, the smallest sized nanoparticles. The SPR bands obtained from solutions with $2 \mathrm{mM}$ of $\mathrm{AgNO}_{3}$ were uniform with narrower peaks, which suggested monodispersity of the nanoparticles without aggregation [25].

The absorbance/intensity increased with concentration owing to the increasing amount of $\mathrm{Ag}$ nanoparticles with the concentration of precursor $\mathrm{AgNO}_{3}$. A decrease in intensity is ascribed to depletion of stable nanoparticles and possible agglomeration [26]. The SPR band for the solution with 1:5 ratio from the $5 \mathrm{mM} \mathrm{AgNO}_{3}$ has the highest intensity (Fig. 3 a) compared to the others. This could be attributed to the availability of more silver ions that were reduced to nanoparticles (NPs).

In general, SPR bands obtained using $2 \mathrm{mM} \mathrm{AgNO}_{3}$ were more uniform and sharper than those obtained using 1 and $5 \mathrm{mM} \mathrm{AgNO}$ concentration, signifying the presence of smaller sized nanoparticles with monodispersity.

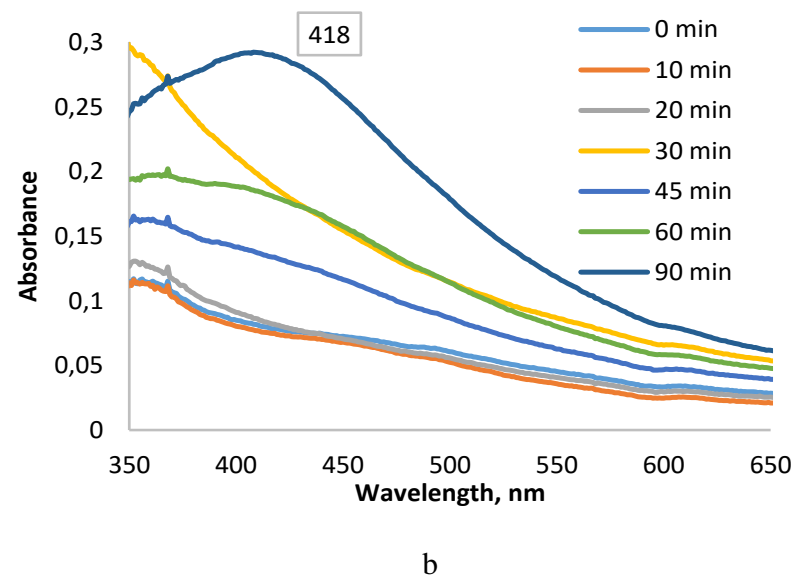

Fig. 1. Absorption spectra of nanoparticles: $a$-synthesized using 1:5 ratio of plant extract to $\mathrm{AgNO}_{3} ; \mathrm{b}-1: 10$ ratio of plant extract to $\mathrm{AgNO}_{3}$ (at $1 \mathrm{mM} \mathrm{AgNO} 3$ concentration) 


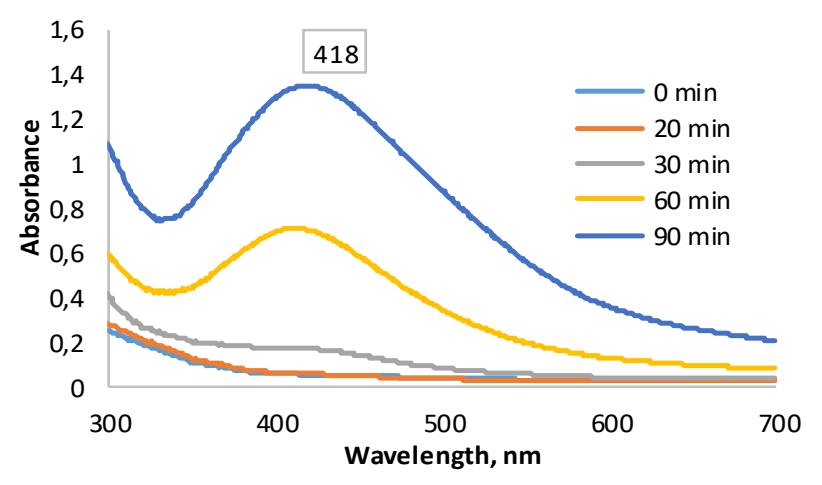

a

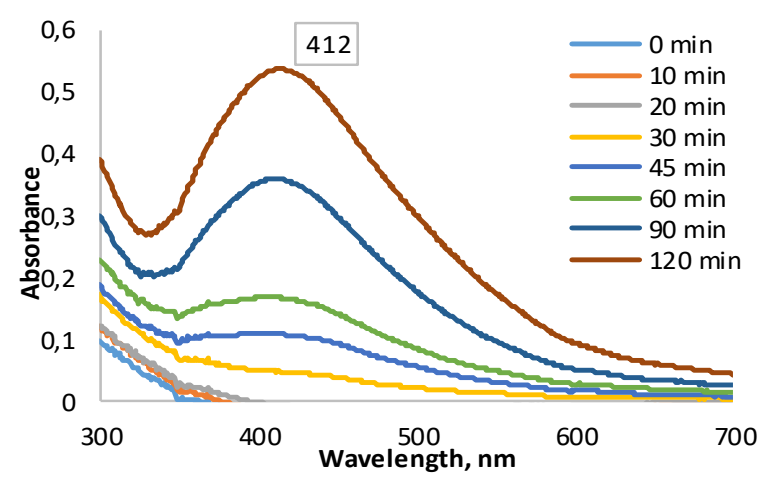

b

Fig. 2. Absorption spectra of nanoparticles: $a$-synthesized using 1:5 ratio of plant extract to $\mathrm{AgNO}_{3} ; \mathrm{b}-1: 10$ ratio of plant extract to $\mathrm{AgNO}_{3}$ (at $2 \mathrm{mM} \mathrm{AgNO} 3$ concentration)

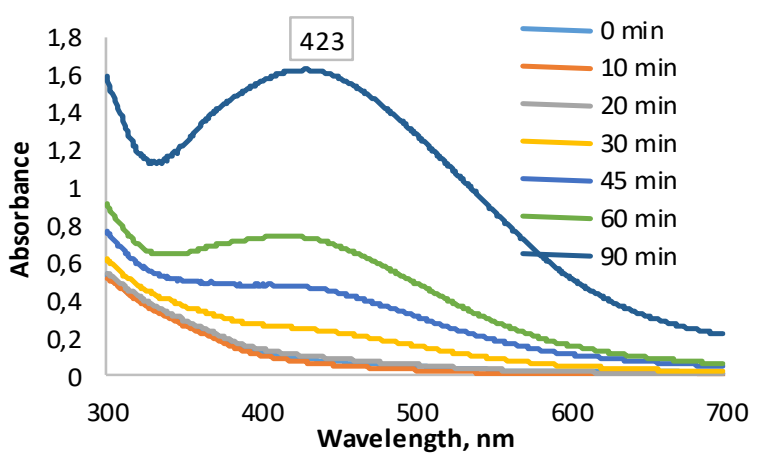

a

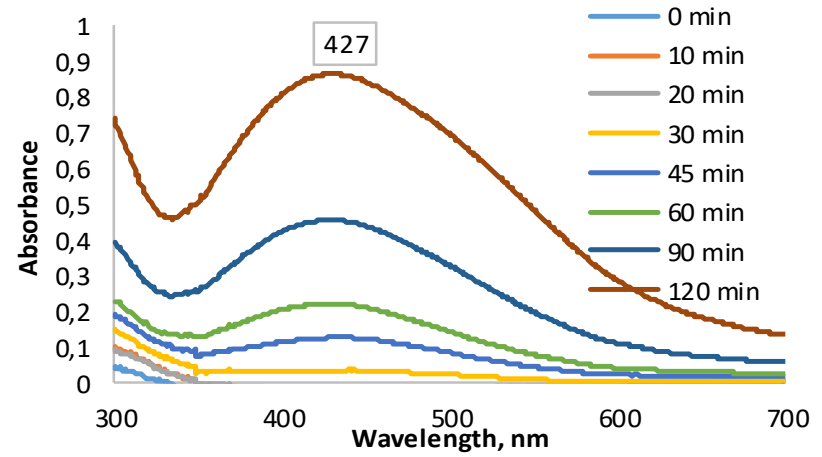

b

Fig. 3. Absorption spectra of nanoparticles: $a-$ synthesized using 1:5 ratio of plant extract to $\mathrm{AgNO}_{3} ; \mathrm{b}-1: 10$ ratio of plant extract to $\mathrm{AgNO}_{3}$ (at $5 \mathrm{mM} \mathrm{AgNO}$ concentration)

This observation was contrary to some earlier studies, which reported decrease in the wavelength of the SPR bands and increase in the sharpness of the absorption peaks [27] with increase in the concentration of $\mathrm{AgNO}_{3}$.

\subsection{Fourier transform infrared (FTIR) analysis}

Fourier transform infrared (FTIR) analysis has become an essential tool for exploring the surface of nanoparticles, as it confirms the presence of biomolecules which functions as capping and stabilization agents for the nanoparticles. In the FTIR spectrum of the leaf extract, broad peak around $3212 \mathrm{~cm}^{-1}$ is assigned to the stretching vibrations of $\mathrm{OH}$ groups of phenols or alcohol components of the plant (Fig. 4). Similar peak was observed in the spectrum of the nanoparticles around $3268 \mathrm{~cm}^{-1}$ indicating the participation of alcoholic or phenolic components of the plant extract in the capping and stabilising of the nanoparticles. The sharp peak around $2918 \mathrm{~cm}^{-1}$ is assigned to the stretching vibrations of aliphatic $\mathrm{CH}$ groups (alkanes) in the plant. This peak also appeared in the spectrum of the nanoparticles around $2921 \mathrm{~cm}^{-1}$. The peak around $2101 \mathrm{~cm}^{-1}$ was due to vibration arising from the presence of $\mathrm{C} \equiv \mathrm{C}$ groups in the plant extract, while that of $\mathrm{C}=\mathrm{C}$ groups appeared around $1571 \mathrm{~cm}^{-1}$. In the spectrum of the nanoparticles, these peaks occurred around 2112 and $1603 \mathrm{~cm}^{-1}$ respectively.
The peaks in the range $1013-1238 \mathrm{~cm}^{-1}$ was assigned to the stretching vibration of $\mathrm{C}-\mathrm{O}$ and $\mathrm{C}-\mathrm{N}$ groups in the plant extract, and they appeared in the range $1024-1292 \mathrm{~cm}^{-1}$ in the spectra of the nanoparticles.

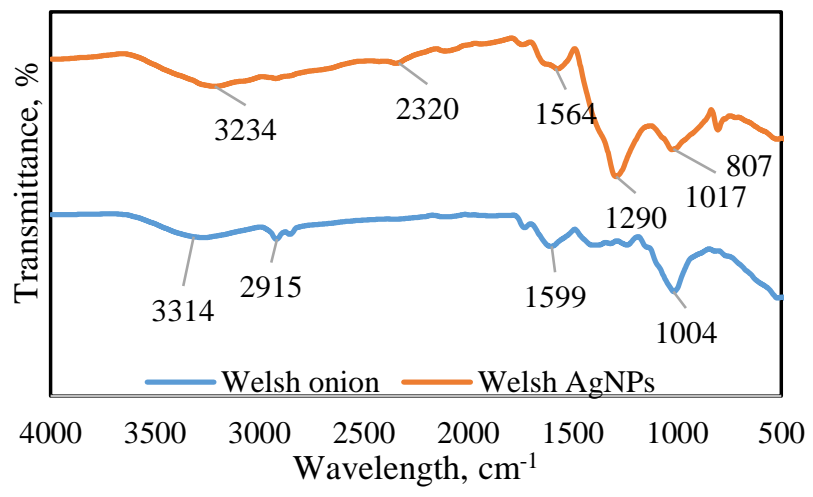

Fig. 4. FTIR spectrum

The appearance of similar peaks in the spectrum of the plant extracts at a higher or lower wavenumber in the spectrum of the nanoparticles confirms the absorption of the plant components on the surface of the nanoparticles [28-31]. Table 1 presents a summary of the functional groups present in the aqueous extract of Welsh onion plant and on the surface of the nanoparticles. 
Table 1. Functional groups present in the Welsh onion plant and nanoparticles

\begin{tabular}{|l|c|c|l|}
\hline \multirow{2}{*}{$\begin{array}{l}\text { Functional } \\
\text { groups }\end{array}$} & \multicolumn{2}{|c|}{ Frequency $\mathrm{cm}^{-1}$} & \multirow{2}{*}{ Intensity } \\
\cline { 2 - 3 } & Welsh onion plant & WoAgNPs & \\
\hline $\mathrm{OH}$ & 3212 & 3268 & strong, broad \\
\hline $\mathrm{C}-\mathrm{H}$ & 2918 & 2921 & strong \\
\hline $\mathrm{C} \equiv \mathrm{C}$ & 2101 & 2112 & variable \\
\hline $\mathrm{C}=\mathrm{O}$ & 1729 & 1739 & strong \\
\hline $\mathrm{C}=\mathrm{C}$ & 1571 & 1603 & strong \\
\hline $\mathrm{C}-\mathrm{O}$ & 1238 & 1292 & strong \\
\hline $\mathrm{C}-\mathrm{O}, \mathrm{C}-\mathrm{N}$ & 1013 & 1024 & strong \\
\hline $\mathrm{C}-\mathrm{Cl}$ & 803 & 816 & strong \\
\hline
\end{tabular}

\subsection{TEM analysis of WoAg-NPs}

The TEM images of the synthesized Ag-NPs are presented in Fig. 5 and Fig. 6, and size range as well as the average particle sizes are summarised in Table 2.
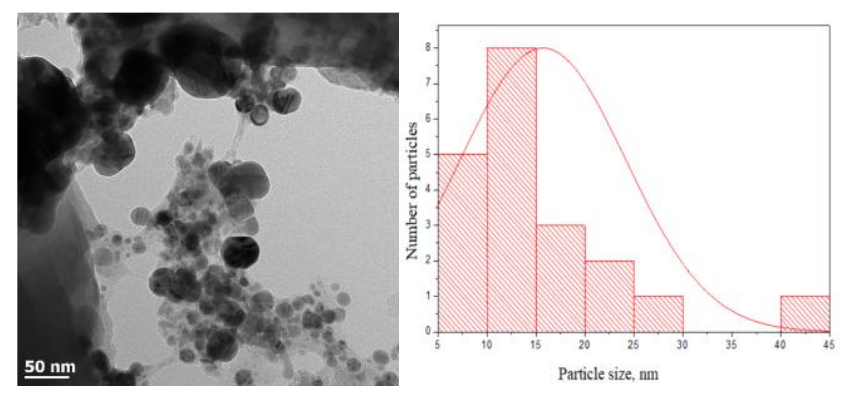

a
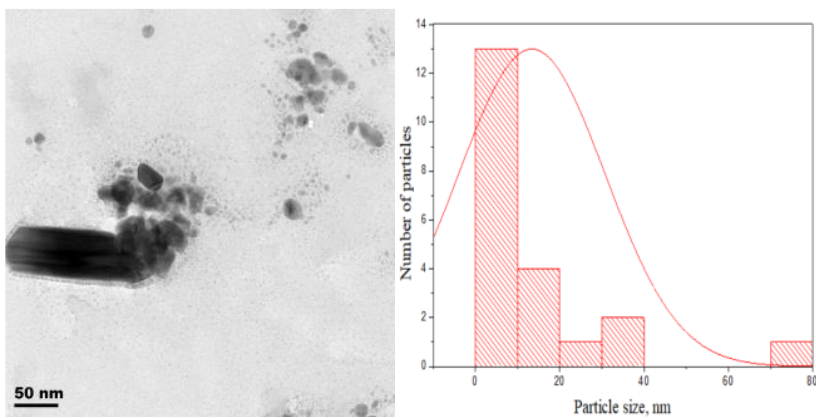

$\mathrm{b}$

Fig. 5. TEM images and particle size distribution histogram of the AgNPs obtained using $1 \mathrm{mM} \mathrm{AgNO}_{3}$ and at: a-1:5; $\mathrm{b}-1: 10$ volume ratio of aqueous plant extract to $\mathrm{AgNO}_{3}$

Table 2. Size distribution of AgNPs from different precursor conc

\begin{tabular}{|c|c|c|c|}
\hline $\begin{array}{l}\text { Conc. of } \\
\text { precursor } \\
\left(\mathrm{AgNO}_{3}\right), \mathrm{mM}\end{array}$ & $\begin{array}{c}\text { Ratio of } \\
\text { substrate to } \\
\text { precursor }\end{array}$ & $\begin{array}{c}\text { Av. size } \\
\text { AgNPs, nm }\end{array}$ & $\begin{array}{c}\text { Size range, } \\
\mathrm{nm}\end{array}$ \\
\hline \multirow{2}{*}{1} & $1: 5$ & 15.72 & $6.20-41.97$ \\
\cline { 2 - 4 } & $1: 10$ & 13.39 & $1.26-78.39$ \\
\hline \multirow{2}{*}{2} & $1: 5$ & 8.03 & $3.05-12.59$ \\
\cline { 2 - 4 } & $1: 10$ & 3.74 & $1.89-9.47$ \\
\hline \multirow{2}{*}{5} & $1: 5$ & 10.29 & $5.42-18.81$ \\
\hline
\end{tabular}

The data showed that the smallest average nanoparticle sizes ( 8.03 and $3.74 \mathrm{~nm})$ were obtained from the solution of $2 \mathrm{mM}$ of $\mathrm{AgNO}_{3}$ with 1:5 and 1:10 ratio of plant extract to $\mathrm{AgNO}_{3}$ respectively. However, the solution of containing
$1 \mathrm{mM}$ of $\mathrm{AgNO}_{3}$ (1:5) gave the largest average particle size of $15.72 \mathrm{~nm}$.
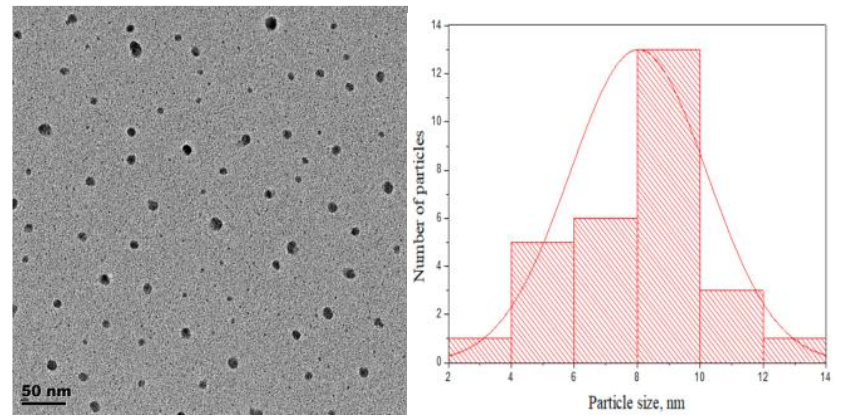

a
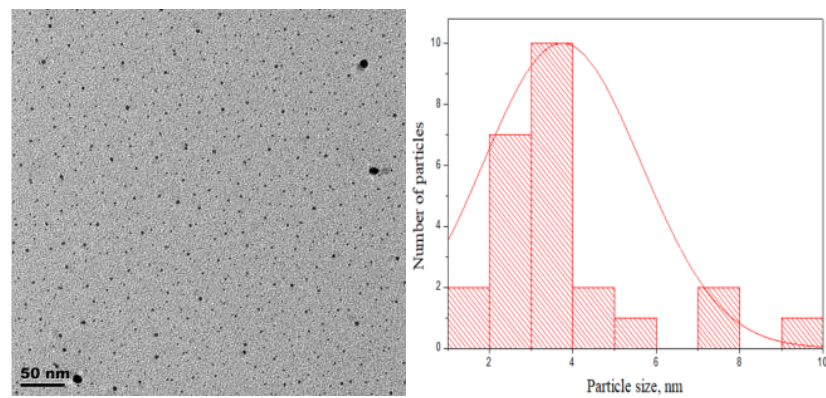

b

Fig. 6. TEM images and particle size distribution histogram of the AgNPs obtained using $2 \mathrm{mM} \mathrm{AgNO}_{3}$ and at: a-1:5; $\mathrm{b}-1: 10$ volume ratio of aqueous plant extract to $\mathrm{AgNO}_{3}$
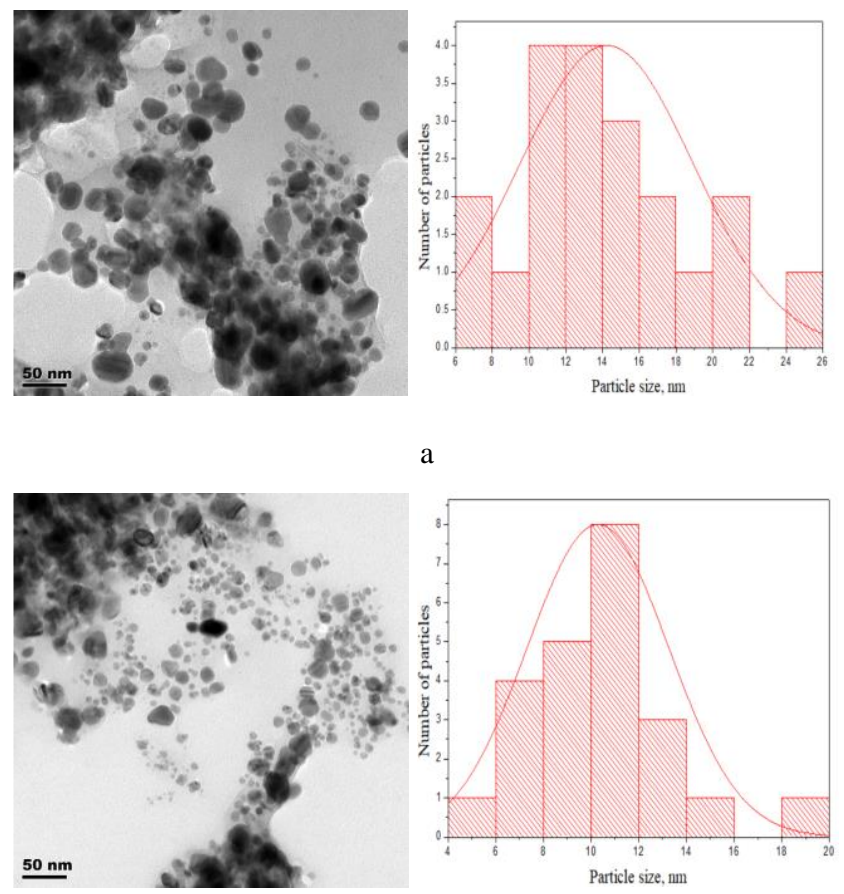

$\mathrm{b}$

Fig. 7. TEM images and particle size distribution histogram of the AgNPs obtained using $5 \mathrm{mM} \mathrm{AgNO}_{3}$ and at: a-1:5; $\mathrm{b}-1: 10$ volume ratio of aqueous plant extract to $\mathrm{AgNO}_{3}$

Silver nanoparticles obtained from the solution of $1 \mathrm{mM} \mathrm{AgNO}_{3}$ (1:10), gave a wide range of particle sizes in the range $1.26-78.39 \mathrm{~nm}$. The large nanoparticles were observed as nanoblocks, while the smaller nanoparticles 
tend to grow on the existing large particles (Fig. 5 b). This could be as a result of weak surface interaction which initiated growth aggregation of smaller particles to form larger ones [32]. Nanoparticles obtained from solution of $2 \mathrm{mM} \quad \mathrm{AgNO}_{3}$ were monodispersed with very good spherical morphology (Fig. 6). Generally, from the results presented in Table 2, there was no correlation between the increase in the concentration of the $\mathrm{AgNO}_{3}$ precursor and the sizes and shapes of the silver nanoparticles. This was different from results obtained from other plant mediated synthesis of silver nanoparticles [33, 34], as increase in the concentration of $\mathrm{AgNO}_{3}$ in the reaction mixture is expected to result to a decrease in the average sizes of the nanoparticles obtained [35].

\subsection{Powder X-ray diffraction (p-XRD) studies}

The p-XRD patterns of the AgNPS are shown in Fig. 8. The diffraction peaks at 39.08, 64.39 and 76.50 are assigned to the (111), (220) and (311) planes of face centred cubic silver nanoparticles.

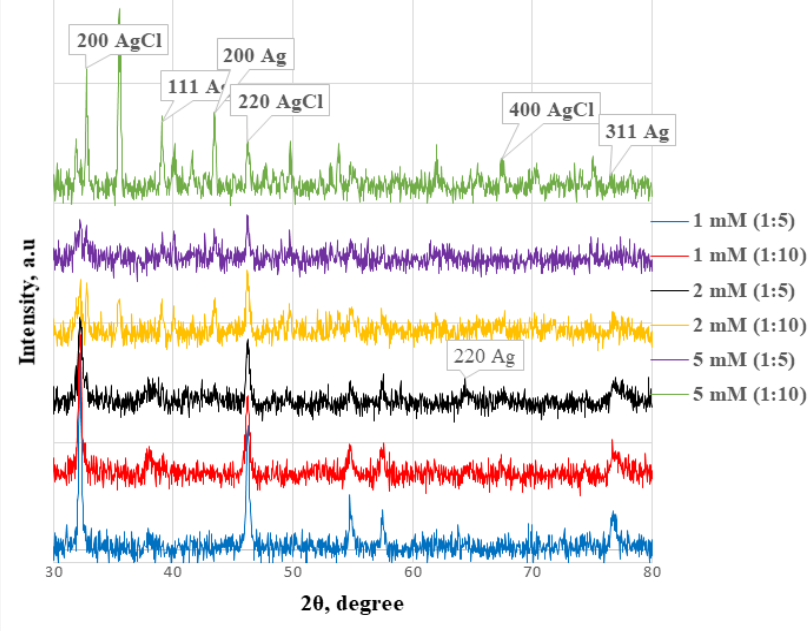

Fig. 8. pXRD patterns of the WoAgNPs obtained using different concentrations of precursor $\mathrm{AgNO}_{3}$ and at different ratio of precursor to plant extract

The peaks at $32.73,46.14,53.86,57.50$ and 67.61 are reflections of (200), (220), (311), (222) and (400) of cubic structured $\mathrm{AgCl}$ [36]. Other peaks in the diffraction pattern could be as a result of precipitation of some bio-materials within the system. In addition, the appearance of more peaks with increasing concentration of the precursor $\mathrm{AgNO}_{3}$ may be due to incomplete reduction of the compounds and the presence of $\mathrm{Ag}_{2} \mathrm{O}$. The reaction conditions, substrate type and other factors immensely affect the biotransformation of $\mathrm{Ag}^{+}$ions to $\mathrm{AgCl}$.

Generally, the biological extracts contain different compounds and ions which, upon reaction with precursor compounds, may give rise to different nanoparticles with diverse shapes. In this study, the Welsh onion produced mixture of spherical $\mathrm{Ag} / \mathrm{AgCl}$ nanoparticles of very small sizes. There are other reports of $\mathrm{Ag} / \mathrm{AgCl}$ nanoparticles with different shapes, which result from various reaction conditions. Patil et al. [37] reported spherical $\mathrm{Ag} / \mathrm{AgCl}$ nanoparticles with diameter between $10-30 \mathrm{~nm}$ obtained using the Sasa borealis leaf extract as stabilizing and capping agent. In another report, $\mathrm{AgCl}$ nanoparticles was reported with size of about $12 \mathrm{~nm}$ which are comparable to the sizes reported in this study [38]. Helmlinger et al. [39] reported the existence of silver nanoparticles of different sizes and shapes under different reaction methods.

\subsection{Photocatalytic activity of WoAgNPs}

Photocatalytic activity of silver nanoparticles is attributed to the migration of charges on the surface of the nanoparticles when irradiated by an electromagnetic radiation leading to interfacial transfer between the metal and dielectric medium [26]. The photocatalytic behaviour of the silver nanoparticles obtained from the solution of 1 and $5 \mathrm{mM}$ of $\mathrm{AgNO}_{3}$ (1:5) was monitored at different intervals using a UV-vis spectroscopy. The degradation of the organic dye (methyl red) was measured at $438 \mathrm{~nm}$, and the differences in absorbance were obtained and presented in Fig. 9 and in Table 3.

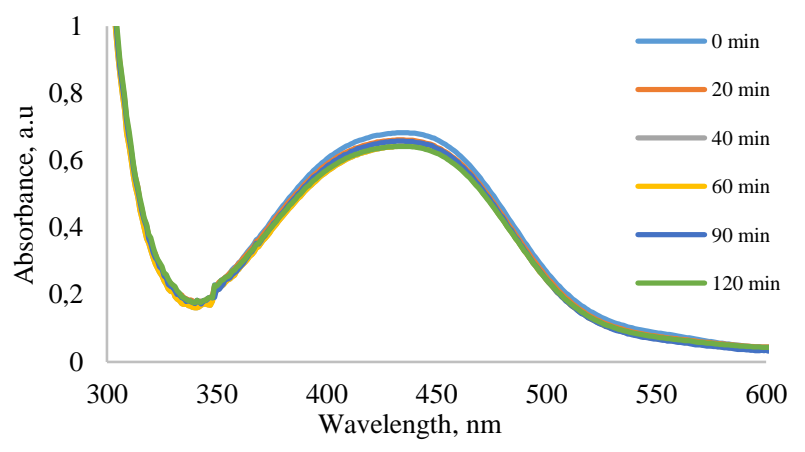

a

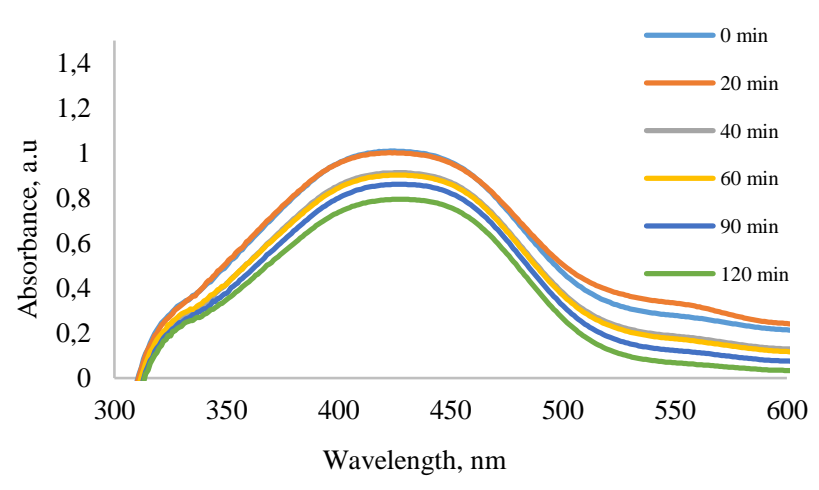

b

Fig. 9. Degradation of methyl red using WoAg-NPs obtained from: $\mathrm{a}-1 \mathrm{mM} ; \mathrm{b}-5 \mathrm{mM} \mathrm{AgNO}_{3}$ using ratio $1: 5$ of $\mathrm{AgNO}_{3}$ to aqueous leaf extract

Table 3. Percentage degradation of methyl red using WoAgNPs

\begin{tabular}{|c|c|c|c|c|}
\hline \multirow{2}{*}{ Time, min } & \multicolumn{2}{|c|}{$1 \mathrm{~mm}(1: 5)$} & \multicolumn{2}{c|}{$5 \mathrm{~mm}(1: 5)$} \\
\cline { 2 - 5 } & Absorbance & $\begin{array}{c}\% \\
\text { degradation }\end{array}$ & Absorbance & $\begin{array}{c}\% \\
\text { degradation }\end{array}$ \\
\hline 0 & 0.6824 & - & 1.0082 & - \\
\hline 20 & 0.6601 & 3.26 & 0.9983 & 1.00 \\
\hline 40 & 0.6423 & 5.87 & 0.9023 & 10.50 \\
\hline 60 & 0.6423 & 5.87 & 0.8610 & 14.60 \\
\hline 90 & 0.6413 & 6.02 & 0.8610 & 14.60 \\
\hline 120 & 0.6410 & 6.07 & 0.7939 & 21.25 \\
\hline
\end{tabular}

The results showed that in the first $20 \mathrm{~min}$ of the reaction, only $3.26 \%$ degradation of methyl orange dye was obtained for the $1 \mathrm{mM}$ precursor concentration and $1.00 \%$ 
for $5 \mathrm{mM} \mathrm{AgNO}_{3}$ solution. In the overall time of the evaluation, the highest degradation obtained was $6.07 \%$ for the particles obtained using $1 \mathrm{mM}$ concentration and $21.25 \%$ for the ones derived using $5 \mathrm{mM}$ WoAg-NPs.

\subsection{Antibacterial analysis}

Silver has over the years been known for its good antimicrobial property and has been utilized for the production of antibiotics such as Silverderm and in water treatment. However, the existence of antibiotic resistant microbes necessitated continued research towards the development of novel antibiotics. Plant mediated silver nanoparticles have been reported to exhibit antimicrobial properties [19, 40,41]. The silver nanoparticles obtained from $2 \mathrm{mM}$ of $\mathrm{AgNO}_{3}$ (1:10) solution were assessed against Gram positive Staphylococcus aureus and Bacillus cerues and Gram negative Kleb.pneumonia and E.coli bacteria strains. The choice of the bacterial strains was due to their pathogenic potentials as food or water contaminants leading to gastrointestinal disorders [41]. The results are shown in Table 4.

The bacterial organisms were susceptible to silver nanoparticles at a concentration of $0.5 \mathrm{mg} / \mathrm{mL}$ in aqueous solution. The antibacterial activity of the nanoparticles was determined as a function of inhibitory zones which was in the range $11.1-19.8 \mathrm{~mm}$. E.coli was most susceptible to the silver nanoparticles while B.cereus was the least susceptible. The antibacterial results of the silver nanoparticles were higher than previously reported in literature [42].

Table 4. Antibacterial results of AgNPs (Zone of inhibition in $\mathrm{mm})$

\begin{tabular}{|l|c|c|c|c|}
\hline Samples & S.aureus & B.cereus & K.pneumonia & E.coli \\
\hline WoAgNPs & $17.3 \pm 0.7$ & $11.1 \pm 1.2$ & $15.4 \pm 0.3$ & $19.8 \pm 1.2$ \\
\hline Ciprofloxacin & $20.0 \pm 1.4$ & $25.8 \pm 0.0$ & $23.0 \pm 0.0$ & $25.0 \pm 0.7$ \\
\hline Water & $\mathrm{R}$ & $\mathrm{R}$ & $\mathrm{R}$ & $\mathrm{R}$ \\
\hline $\begin{array}{l}\text { Ciprofloxacin is the standard antibacterial drug used in this analysis and } \\
\text { it served as a positive control whereas water is used as negative control. } \\
\mathrm{R}=\text { resistant. The values (in mm) represent the mean of double } \\
\text { replications and their standard deviation. }\end{array}$ \\
\hline
\end{tabular}

The antibacterial results were classified according to the following scale: inhibition zones down to $9 \mathrm{~mm}$, inactive; $9-12 \mathrm{~mm}$, moderately active; $13-18 \mathrm{~mm}$, active; above $18 \mathrm{~mm}$, very active [18]. Based on the scale, the nanoparticles could be said to be very active against $E$. coli, active against $K$. pneumonia and $S$. aureus and moderately active against $B$. cereus at a concentration of $0.5 \mathrm{mg} / \mathrm{mL}$.

The minimum inhibitory concentration of the silver nanoparticles against the microbes was evaluated using concentrations of $0.05-0.25 \mathrm{mg} / \mathrm{mL}$ and presented in Table 5.

Table 5. Minimum inhibitory concentration (MIC)

\begin{tabular}{|l|c|c|c|c|}
\hline Samples & S.aureus & B.cerues & K.pneumonia & E.coli \\
\hline AgNPs & $<0.05$ & 0.1 & 0.1 & $<0.05$ \\
\hline Ciprofloxacin & $<0.05$ & $<0.05$ & $<0.05$ & $<0.05$ \\
\hline
\end{tabular}

From the result, the nanoparticle gave MIC results lower than $0.05 \mathrm{mg} / \mathrm{mL}$ against Staphylococcus aureus and E. coli, while the MIC results of particles against Bacillus cereus and Klebsiella pneumonia was $0.1 \mathrm{mg} / \mathrm{mL}$. Hence, the nanoparticles are more active against $E$. coli than the other bacteria strains.

\section{CONCLUSIONS}

Silver nanoparticles were prepared via plant-mediated technique using different volumes of crude extracts of Welsh onion plant and different concentration of $\mathrm{AgNO}_{3}$. The nanoparticles showed varying sizes and morphology, which depicted the change in the reaction conditions used. From $2 \mathrm{mM}$ precursor concentrations, spherical nanoparticles of about $2.00-13.00 \mathrm{~nm}$ size range was obtained, but the other concentrations (1 and $5 \mathrm{mM}$ ) gave nanoparticle with larger sizes and some degrees of agglomeration. The $\mathrm{p}$-XRD studies revealed the formation of face centred cubic phase of Ag nanoparticles and with $\mathrm{AgCl}$ peaks. FTIR results showed the presence of different functional groups responsible for the bioreduction of silver ions in Welsh onion plant extract. The nanoparticles obtained from 1 and $5 \mathrm{mM}$ (1:5) of $\mathrm{AgNO}_{3}$ solution showed moderate photo-catalysts potentials in the degradation of methyl orange dye. The photocatalytic ability increased with increase in concentration of the precursor $\mathrm{AgNO}_{3}$ salt from 1 to $5 \mathrm{mM}$. Gram positive Staphylococcus aureus and Bacillus cereus, and Gram negative Klebsiella pneumonia and Escherichia coli bacteria strains were susceptible to the silver nanoparticles obtained from $2 \mathrm{mM}(1: 10)$ of $\mathrm{AgNO}_{3}$ solution. The nanoparticles were most active against E.Coli with an MIC of $0.05 \mathrm{mg} / \mathrm{mL}$. The silver nanoparticles may become lead compounds in future antibiotic research.

\section{Acknowledgments}

The authors wish to thank Dr Anine for the TEM analysis and the Department of Chemistry, NWU South Africa for providing the platform for carrying out this study.

\section{REFERENCES}

1. Harush-Frenkel, O., Debotton, N., Benita, S., Altschuler, Y. Targeting of Nanoparticles to the ClathrinMediated Endocytic Pathway Biochemical and Biophysical Research Communications 353 (1) 2007: pp. 26-32. https://doi.org/10.1016/j.bbrc.2006.11.135

2. Tejamaya, M., Römer, I., Merrifield, R.C., Lead, J.R. Stability of Citrate, Pvp, and Peg Coated Silver Nanoparticles in Ecotoxicology Media Environmental Science \& Technology 46 (13) 2012: pp. 7011-7017. https://doi.org/10.1021/es2038596

3. Levard, C., Hotze, E.M., Lowry, G.V., Brown, G.E. Environmental Transformations of Silver Nanoparticles: Impact on Stability and Toxicity Environmental Science \& Technology 46(13) 2012: pp. 6900-6914. https://doi.org/10.1021/es2037405

4. Cha, K., Hong, H.W., Choi, Y.G., Lee, M.J., Park, J.H., Chae, H.K., Ryu, G., Myung, H. Comparison of Acute Responses of Mice Livers to Short-Term Exposure to NanoSized or Micro-Sized Silver Particles Biotechnology Letters 30 (11) 2008: pp. $1893-1899$. https://doi.org/10.1007/s10529-008-9786-2

5. Chung, Y.C., Chen, I.H., Chen, C.J. The Surface Modification of Silver Nanoparticles by Phosphoryl Disulfides for Improved Biocompatibility and Intracellular Uptake Biomaterials $29(12)$ 2008: pp. 1807-1816. https://doi.org/10.1016/j.biomaterials.2007.12.032 
6. Kuhn, D.A., $\quad$ Vanhecke, D., Michen, B., Blank, F., Gehr, P., Petri-Fink, A., Rothen-Rutishauser, B. Different Endocytotic Uptake Mechanisms for Nanoparticles in Epithelial Cells and Macrophages Beilstein Journal of Nanotechnology 5 2014: pp. 1625-1636.

https://doi.org/1010.3762/bjnano

7. Helmlinger, J., Sengstock, C., Gross-Heitfeld, C., Mayer, C., Schildhauer, T.A., $\quad$ Köller, M., Epple, M. Silver Nanoparticles with Different Size and Shape: Equal Cytotoxicity, but Different Antibacterial Effect RSC Advances 6 2016: pp. 18490-18501. https://doi.org/10.1039/C5RA27836H

8. Dakal, T.C., Kumar, A., Majumdar, R.S., Yadav, V. Mechanistic Basis of Antimicrobial Actions of Silver Nanoparticles Frontiers in Microbiology 7 2016: pp. $1831-1831$.

https://doi.org/10.3389/fmicb.2016.01831

9. Pal, S., Tak, Y.K., Song, J.M. Does the Antibacterial Activity of Silver Nanoparticles Depend on the Shape of the Nanoparticle? A Study of the Gram-Negative Bacterium Escherichia Coli Applied and Environmental Microbiology 73 (6) 2007: pp. 1712-1720. https://doi.org/10.1128/AEM.02218-06

10. Erjaee, H., Rajaian, H., Nazifi, S. Synthesis and Characterization of Novel Silver Nanoparticles Using Chamaemelum Nobile Extract for Antibacterial Application Advances in Natural Sciences: Nanoscience and Nanotechnology 8 (2) 2017: pp. 025004. https://doi.org/1010.1088/2043-6254/aa690b

11. Li, Z., Lee, D., Sheng, X., Cohen, R.E., Rubner, M.F. Two-Level Antibacterial Coating with Both Release-Killing and Contact-Killing Capabilities Langmuir 22 (24) 2006: pp. $9820-9823$.

https://doi.org/10.1021/la0622166

12. Panáček, A., Kvítek, L., Prucek, R., Kolář, M., Večeřová, R., Pizúrová, N., Sharma, V.K., Nevěčná, T.J., Zbořil, R. Silver Colloid Nanoparticles: Synthesis, Characterization, and Their Antibacterial Activity The Journal of Physical Chemistry B 110 (33) 2006: pp. $16248-16253$. https://doi.org/10.1021/jp063826h

13. Vidyalakshmi, N., Thomas, R., Aswani, R., Gayatri, G.P., Radhakrishnan, E.K., Remakanthan, A. Comparative Analysis of the Effect of Silver Nanoparticle and Silver Nitrate on Morphological and Anatomical Parameters of Banana under in Vitro Conditions Inorganic and NanoMetal Chemistry $47(11)$ 2017: pp. 1530-1536. https://doi.org/10.1080/24701556.2017.1357605

14. Sobolewska, D., Podolak, I., Makowska-Wąs, J. Allium Ursinum: Botanical, Phytochemical and Pharmacological Overview. Phytochemistry Reviews 14(1) 2015: pp. 81-97. https://doi.org/10.1007/s11101-013-9334-0

15. Sharma, P., Kaur, A., Kaur, S. Nutritional Quality of Flours From Guar Bean (Cyamopsis Tetragonoloba) Varieties as Affected by Different Processing Methods Journal of Food Science and Technology 54(7) 2017: pp. 1866-1872.

https://doi.org/10.1007/s13197-017-2618-4

16. Vlase, L., Parvu, M., Parvu, E.A., Toiu, A. Chemical Constituents of Three Allium Species from Romania Molecules 18 (1) 2013: pp. 114-127. https://doi.org/10.3390/molecules18010114

17. Tendaj, M., Mysiak, B. Usefulness of Japanese Bunching Onion [Allium Fistulosum L.] for Forcing in Greenhouse Acta Agrobotanica 60 (1) 2007: pp. 143-146. https://doi.org/10.5586/aa.2007.017

18. Takahashi, M., Shibamoto, T. Chemical Compositions and Antioxidant/Anti-Inflammatory Activities of Steam Distillate from Freeze-Dried Onion (Allium Cepa L.) Sprout Journal of Agricultural and Food Chemistry $56(22)$ 2008: pp. $10462-10467$.

https://doi.org/10.1021/jf801220b

19. Elemike, E.E., Onwudiwe, D.C., Ekennia, A.C., KatataSeru, L. Biosynthesis, Characterization, and Antimicrobial Effect of Silver Nanoparticles Obtained Using Lavandula $\times$ Intermedia Research on Chemical Intermediates 43 (3) 2017: pp. $1383-1394$. https://doi.org/10.1007/s11164-016-2704-7

20. Elemike, E.E., Onwudiwe, D.C., Ekennia, A.C., Ehiri, R.C., Nnaji, N.J. Phytosynthesis of Silver Nanoparticles Using Aqueous Leaf Extracts of Lippia Citriodora: Antimicrobial, Larvicidal and Photocatalytic Evaluations Materials Science and Engineering: $C 75$ 2017: pp. $980-989$. https://doi.org/10.1016/j.msec.2017.02.161

21. Onwudiwe, D.C., Krüger, T.P.J., Jordaan, A., Strydom, C.A. Laser-Assisted Synthesis, and Structural and Thermal Properties of Zns Nanoparticles Stabilised in Polyvinylpyrrolidone Applied Surface Science 321 2014: pp. $197-204$. https://doi.org/10.1016/j.apsusc.2014.10.022

22. Alves, T.M.d.A., Silva, A.F., Brandão, M., Grandi, T.S.M., Smânia, E.d.F.A., Smânia Júnior, A., Zani, C.L. Biological Screening of Brazilian Medicinal Plants Memórias do Instituto Oswaldo Cruz 95 (3) 2000: pp. 367-373.

https://doi.org/10.1590/s0074-02762000000300012

23. Bin Ahmad, M., Tay, M.Y., Shameli, K., Hussein, M.Z., Lim, J.J. Green Synthesis and Characterization of Silver/Chitosan/Polyethylene Glycol Nanocomposites without Any Reducing Agent International Journal of Molecular Sciences 12 (8) 2011: pp. 4872-4884. https://doi.org/10.3390/ijms12084872

24. Kelly, K.L., Coronado, E., Zhao, L.L., Schatz, G.C. The Optical Properties of Metal Nanoparticles: The Influence of Size, Shape, and Dielectric Environment The Journal of Physical Chemistry B 107 (3) 2003: pp. 668-677. https://doi.org/10.1021/jp026731y

25. AL-Kazazz, F.F.M., AL-Imarah, K.A.F., ALHasnawi, I.A., Agelmashotjafar, L., AbdulMajeed, B.A. A Simple Method for Synthesis, Purification and Concentration Stabilized Goldnanoparticles International Journal of Engineering Research and Applications 3 (6) 2013: pp. 21-30.

26. Saion, E., Gharibshahi, E., Naghavi, K. Size-Controlled and Optical Properties of Monodispersed Silver Nanoparticles Synthesized by the Radiolytic Reduction Method International Journal of Molecular Sciences 14 (4) 2013: pp. $7880-7896$. https://doi.org/10.3390/ijms14047880

27. Rao, B., Tang, R.-C. Green Synthesis of Silver Nanoparticles with Antibacterial Activities Using Aqueous Eriobotrya Japonica Leaf Extract Advances in Natural Sciences: Nanoscience and Nanotechnology 8 (1) 2017: pp. 015014. https://doi.org/10.1088/2043-6254/aa5983

28. Ndikau, M., Noah, N.M., Andala, D.M., Masika, E. Green Synthesis and Characterization of Silver Nanoparticles Using Citrullus Lanatus Fruit Rind Extract 
International Journal of Analytical Chemistry

2017: pp. 8108504-8108504.

https://doi.org/10.1155/2017/8108504

29. Devaraj, P., Kumari, P., Aarti, C., Renganathan, A. Synthesis and Characterization of Silver Nanoparticles Using Cannonball Leaves and Their Cytotoxic Activity against Mcf7 Cell Line Journal of Nanotechnology 2013 2013: pp. $1-5$. https://doi.org/10.1155/2013/598328

30. Prabu, J., Johnson, I. Plant-Mediated Biosynthesis and Characterization of Silver Nanoparticles by Leaf Extracts of Tragia Involucrata, Cymbopogon Citronella, Solanum Verbascifolium and Tylophora Ovata Karbala International Journal of Modern Science 1 2015: pp. 237-246. https://doi.org/10.1016/j.kijoms.2015.12.003

31. Sadeghi, B., Gholamhoseinpoor, F. A Study on the Stability and Green Synthesis of Silver Nanoparticles Using Ziziphora Tenuior (Zt) Extract at Room Temperature Spectrochimica Acta Part A: Molecular and Biomolecular Spectroscopy 134 2015: pp. 310-315. https://doi.org/10.1016/j.saa.2014.06.046

32. Panda, S.K., Das, R., Leyssen, P., Neyts, J., Luyten, W. Assessing Medicinal Plants Traditionally Used in the Chirang Reserve Forest, Northeast India for Antimicrobial Activity Journal of Ethnopharmacology 225 2018: pp. 220-233. https://doi.org/10.1016/j.jep.2018.07.011

33. Polte, J. Fundamental Growth Principles of Colloidal Metal Nanoparticles - a New Perspective Crystengcomm 17 (36) 2015: pp. 6809-6830. https://doi.org/10.1039/C5CE01014D

34. Kuppusamy, P., $\quad$ Yusoff, M.M., $\quad$ Maniam, G.P., Govindan, N. Biosynthesis of Metallic Nanoparticles Using Plant Derivatives and Their New Avenues in Pharmacological Applications - an Updated Report Saudi Pharmaceutical Journal 24 (4) 2016: pp. 473-484. https://doi.org/10.1016/j.jsps.2014.11.013

35. Jain, S., Mehata, M.S. Medicinal Plant Leaf Extract and Pure Flavonoid Mediated Green Synthesis of Silver Nanoparticles and Their Enhanced Antibacterial Property Scientific Reports 7 2017: pp. 15867.

https://doi.org/10.1038/s41598-017-15724-8
36. Zhang, X-F., Liu, Z-G., Shen, W., Gurunathan, S. Silver Nanoparticles: Synthesis, Characterization, Properties, Applications, and Therapeutic Approaches, International Journal of Molecular Sciences 17 2016: pp. 1534-1568 https://doi.org/10.3390/ijms17091534

37. Patil, M.P., Palma, J., Simeon, N.C., Jin, X., Liu, X.L., Ngabire, D., Kim, N.H., Tarte, N.H., Kim, G.D. Sasa Borealis Leaf Extract-Mediated Green Synthesis of SilverSilver Chloride Nanoparticles and Their Antibacterial and Anticancer Activities New Journal of Chemistry 41 (3) 2017: pp. $1363-1371$. https://doi.org/10.1039/C6NJ03454C

38. Kumar, D.A., $\quad$ Palanichamy, V., Roopan, S.M. Photocatalytic Action of Agcl Nanoparticles and Its Antibacterial Activity Journal of Photochemistry and Photobiology B: Biology 138 2014: pp. 302-306. https://doi.org/10.1016/j.jphotobiol.2014.06.011

39. Helmlinger, J., Sengstock, C., Gross-Heitfeld, C., Mayer, C., Schildhauer, T.A., Koller, M., Epple, M. Silver Nanoparticles with Different Size and Shape: Equal Cytotoxicity, but Different Antibacterial Effects RSC Advances 6 (22) 2016: pp. 18490-18501. https://doi.org/10.1039/C5RA27836H

40. Elemike, E.E., Onwudiwe, D.C., Ekennia, A.C., Sonde, C.U., Ehiri, R.C. Green Synthesis of $\mathrm{Ag} / \mathrm{Ag}_{2} \mathrm{O}$ Nanoparticles Using Aqueous Leaf Extract of Eupatorium Odoratum and Its Antimicrobial and Mosquito Larvicidal Activities Molecules 22 (5) 2017: pp. 674-689. https://doi.org/10.3390/molecules22050674

41. Wulandari, A.P., Primastia, N., Sajuti, J.N. Sensitivity Escherichia Coli and Staphylococcus Aureus Cause Diarrhea to the Fungi Isolated from Soft Coral. AIP Publishing, City, 2016: pp. 020005. https://doi.org/10.1063/1.4953479

42. Senthil, B., Devasena, T., Prakash, B., Rajasekar, A. NonCytotoxic Effect of Green Synthesized Silver Nanoparticles and Its Antibacterial Activity Journal of Photochemistry and Photobiology B: Biology 177 2017: pp. 1-7. https://doi.org/10.1016/j.jphotobiol.2017.10.010.

(c) Elemike et al. 2020 Open Access This article is distributed under the terms of the Creative Commons Attribution 4.0 International License (http://creativecommons.org/licenses/by/4.0/), which permits unrestricted use, distribution, and reproduction in any medium, provided you give appropriate credit to the original author(s) and the source, provide a link to the Creative Commons license, and indicate if changes were made. 